\title{
The Main Agroecologycal Structure (MAS) of the agroecosystems: concept, methodology and applications
}

Tomás Enrique León-Sicard* Agrólogo, Dr. Full Professor. Universidad Nacional de Colombia - Instituto de Estudios Ambientales (IDEA). Email: teleons@unal.edu.co

José Javier Toro Calderón, Zootecnista, Dr. Associated profesor. Universidad Nacional de Colombia - Instituto de Estudios Ambientales (IDEA). Email: jitoroca@unal.edu.co

Liven Fernando Martinez-Bernal. Agrónomo Dr (c) Assistant Professor, Universidad Nacional de Colombia - Instituto de Estudios Ambientales (IDEA)). Email: Ifmartinezb@unal.edu.co

José Alejandro Cleves-Leguízamo. Agrónomo $\mathrm{Dr}$ (C) Associated Professor Universidad Pedagógica y Tecnológica de Colombia. Email: jose.cleves@uptc.edu.co

*Author for correspondence

\begin{abstract}
This document presents, from environmental thinking (ecosystem - culture relations), the concept of the Main Agroecological Structure of Agroecosystems (MAS), considered as a dissipative cultural structure. It discusses its possible applications (resilience, production, diversity) both inside and outside the farms. The MAS can be useful in the land planning on the farms, based on the concept of potential MAS that allows the quantification of the management of internal and external corridors, including natural vegetation. At the same time, it can be useful in the context of landscape management because it shows a series of cultural relations (economic, social, symbolic and technological) hidden from the partial analysis of landscape ecology.
\end{abstract}

Additional key words: agrobiodiversity, environment, ecosystem, culture, farms, planning.

\section{Introduction}

Environmental thinking in essence raises and recognizes that humanity built a system of adaptation to the ecosystems, different from that of other living beings, based primarily on culture. The culture has been defined as the non-biological heritage of humanity (Tylor, 1871) or as all those theoretical and practical processes that are expressed in the symbolic structures, human organization and technological platforms of humanity (Ángel, 1993, Ángel, 1995, Ángel, 1996). From this point of view, food production systems can be understood as sets of activities that human groups organize, direct and carry out according to their objectives and resources, influencing and being influenced by the ecosystem and biophysical environment where they are located (Duarte, 1990). This aspect denotes the relevance and complexity of the interaction ecosystem-culture in the agrarian field (Ángel, 1996).

On the other hand it is widely accepted that agriculture is the result of the cultural modification of ecosystems, when these transformations apply to satisfy the basic needs of food, fibers and other materials and are amplified according to the conditioning factors of ecosystem coevolution - culture (León-Sicard, 2007, Fonseca and Cleves-Leguízamo 2015). The study of these complex relationships is the object of 
agroecology (León-Sicard, 2014), a science that focuses on the environmental analysis of agroecosystems (Altieri and Nicholls, 2009; Altieri, 2010), recognizing in them multiple biophysical, symbolic, social, economic, political and technological interactions (Altieri et al., 1999).

Agroecology studies and proposes answers to complex problems, through agrarian practices based on traditional or ancestral knowledge, the promotion of biological and cultural diversity, the autonomy of producers and the conservation and proper management of natural resources. It also propose an interdisciplinary approach in scientific research and successfully stimulating biological regulations even in largescale agriculture (León-Sicard, 2010a, León-Sicard, 2010b, Méndez and Gliessman, 2002, Martínez, 2002, Toledo, 1990).

Within these practices or strategies that arise from agroecology, León-Sicard (2010a) proposes to study what he called the Main Agroecological Structure of the major agroecosystems (MAS). This concept refers to the arrangements of the internal and external connectors of the farms (fences, hedges, living fences or patches of forest) and can relate to the probability of resilience or adaptation of agrarian systems to disturbances of different nature. The MAS could be associated theoretically with a Dissipative Structure (ED), with possible beneficial effects on the establishment and development of crops in different scales, from subsistence agriculture in small areas to intensive productive processes of agro industrial character. Likewise, the MAS could allow the design and implementation of adaptation and mitigation options to the changing climate, as a contribution to risk management.

This document presents the theoretical bases of the concept, the general methodology for its calculation and the description of some preliminary applications made in Colombia.

\section{Theoretical bases of the MAS}

The agroecosystem is an ecosystem deliberately modified by human beings in order to obtain goods and services, with different purposes and therefore it is the place where dynamic relations between the culture and its physical-biological environment are presented (Gliessman, 1991; Dalgaard et al., 2003).

Agroecosystems are considered by various authors as units of analysis where different types of ecosystem processes and socio-economic relationships converge (energy flows, material cycles) (Altieri and Nicholls, 2009, Altieri, 2010).

León-Sicard (2010a), defined the agroecosystem as "...the set of relationships and interactions between soils, climates, cultivated plants, organisms of different trophic levels, adventitious plants and human groups in certain physical and geographical spaces. Its study includes their energy flows and information, their material cycles and their symbolic, social, economic and political relations, which are expressed in different technological forms of management within specific cultural contexts... ". The interactions between the components are presented within diffuse limits that can go beyond the farm (Altieri et al., 1999).

The origin of the MAS derived from the works of van der Hammen (1998) and van der Hammen and Andrade (2003) in Colombia, who proposed the idea of the Ecological Support Structure of the Nation (ESS), to facilitate the comprehension, at the country level, of the current state of its plant cover. In this ESS the authors recognized two components: the Main Ecological Structure of the Landscape (MES) and the Ecological 
Infrastructure (EI) and in the latter they included the remnants of vegetation in the agroecosystems, although they did not deepen in their meaning and applications.

With these concepts the authors gave meaning to the study of landscape ecology and provided a background to articulate, in theory and practice, the management of relicts and patches of natural vegetation, including biological corridors and wooded masses. In the concept of Ecological Infrastructure, they introduced the existing natural vegetation in the agroecosystems, but did not advance in the formulation of this idea.

In this way, the concept of the Main Agroecological Structure of agroecosystems is born to accommodate this unfinished relationship proposed by professors van der Hammen and Andrade and to provide a frame of reference for agroecology in terms of a natural property of the Agroecosystems: its own structure.

León-Sicard (2010a), then defined the MAS as "...the internal configuration or spatial arrangement of the farm and the connectivity between its different sectors, patches and corridors of vegetation or productive systems. The MAS allows the movement and exchange of different animal and vegetable species, offers shelter, habitat and food, provides microclimatic regulations and affects the crops yield and the conservation of natural resources and other ecosystem and cultural aspects of the major agroecosystems ".

The major agroecosystem (farm) has an ecosystem content that is expressed in minor agroecosystems (lots, plots, cultivation sites, forest areas, agroforestry sites or silvopastoral systems). The way in which these relate to forests or other types of tree, herbaceous or scrub vegetation cover within the major agroecosystem, gives specific characteristics to the farm's MAS. This concept, which aims to describe the structural and functional relationships of major agroecosystems, in light of the cultural factors that determine them, can be used for different applications (relations with production, plant health, food autonomy, resilience) including future uses as taxonomic criterion of agroecosystems (León-Sicard, 2014).

In the processes of designing agroecosystems resilient to different types of disturbance, it is necessary to understand the complexity inherent in agroecosystems (Altieri and Koohafkan, 2008). In this sense the MAS accounts for both functional (unintentional) and planned agrobiodiversity, offering possibilities for planning through the potential MAS, with repercussions at farm level (crops yields) and also at the level of agroecosystem matrices in landscape units at smaller scales (sidewalks, river basins, municipalities, regions) ( León-Sicard, 2010a).

In agroecosystems, while they are considered as systems far from equilibrium, there are constant exchanges of matter and energy and information flows with the environment, and it is impossible to obtain final and permanent equilibria, due to the continuous entropy generated in their transformation processes. However, these systems evolve adapting to their environment, until they reach the weakest possible dissipation through mechanisms of self-organization or autopoiesis (Maturana y Varela, 2004, Prigogine, 1983, Wagensberg, 1998).

When these systems face disturbances or fluctuations, for example, when agroecosystems are subject to changes in temperature, rainfall or attacks by insects or pathogens and when these disturbances, instead of disappearing, increase, agroecosystems can undergo an organized structural transformation, which would allow maintaining its functionality in time and space, towards a new passenger state called "dissipative structure". This structure is the amplified fluctuation, stabilized by the interactions with the environment, maintaining itself because it is continuously 
nourished by the energetic flow coming from the disturbance (Prigogine, 1983, Prigogine and Lefever, 1973). The formation and maintenance of the dissipative structure requires at least three conditions: (1) the system must be open and can continuously exchange matter and energy with the external environment. (2) The system must be in a state of no equilibrium or far from equilibrium; because nonequilibrium is the source of order (3) Non-linear interactions as well as certain nonlinear dynamic equations must exist in the system (Deng et al., 2017).

Since its promulgation, the theory of dissipative structures has shown a wide scope, currently achieving support for several theoretical frameworks in engineering, medicine, psychology, agriculture and human sciences (Ahn, 1998, Almendro and Weber, 2012, Deng et al., 2017; Marchettini et al., 2010; Pulselli et al., 2009; Shvartsev, 2009; Zhao et al., 2000). For this reason, this Theory is becoming an important reference in the modern scientific system (Zhan and Sheng, 1998).

The concept of dissipative structure was applied in ecology, since the seventies of the last century, to explain the relationships that exist between predators and their prey (Segel and Jackson, 1972) and in the study of biological structure and functions at the genetic level (Martinez and Carlsson, 1974). In the 1980s, it was used to study the evolution of ecosystems (Bazykin et al., 1983) and explain the relationships between species and ecosystems (Emig, 1985). While for the late twentieth century it was applied to the analysis of the distribution of plants (Tuzinkevich and Frisman, 1990) and in the design of processes to manage and control weed plants (Wang, 1992), to name just a few examples.

In summary, the theoretical approach of dissipative structures can be applied to explain the behavior of biological, physical, chemical and social systems and to study the evolution of their structures in terms of a certain "order acquisition" (Wagensberg, 1998) and for the analysis of systems resilience.

If the agroecosystem is considered an open system that interacts constantly with the environment (physical, biotic, social, economic and cultural), the MAS can also be considered as a dissipative structure, which allows the system to increase or improve the possibilities of maintaining its functionality, incorporating, dissipating or using the matter, energy or information coming from the disturbance. In this sense, for example, the greatest available agrobiodiversity in a farm allows the different plants located in diversified strata and with diverse phenotypes and genotypes, to have greater physical resistance to climatic disturbances, but also wide ranges of response in economic and social terms to disturbances of different origins and class.

Sizing the MAS as a dissipative structure allows us to analyze the components of the agroecosystem and strengthen those that can dissipate the disturbance. For example, in the event of a disturbance related to the increase in evapotranspiration or the decrease in available water, it is possible to use species that are more resistant, to use green cover to protect the soil or other strategies, which are themselves the consequence of social or economic processes. It would also make it possible to direct efforts to propose solutions of a cultural nature such as saving water or collecting rain, mediated by the cultural characteristics of particular agrarian societies.

Assuming this theoretical approach to thermodynamics, MAS could be considered as a cultural dissipative structure that, insofar as it increases, improves the possibilities of interaction and adaptation to different types of disturbances, due to the inherent complexity of greater agrobiodiversity and connectivity between sectors of agroecosystems. In this way, the greater MAS (structured) would help to dispel the negative effects of external factors, whether cultural or ecosystemic. 


\section{Methodology approach}

The criteria proposed by León-Sicard et al., 2012; Córdoba and León-Sicard, 2013 and León-Sicard et al., 2014, aimed at evaluating the MAS, corresponds to the sum of the parameters indicated in Table 1. Figures 1 and 2 show examples of some parameters measured in farms of the Colombian Orinoquia.

Table 1. Evaluative parameters to estimate the Main Agroecological Structure

\begin{tabular}{|c|c|c|}
\hline Parameter & Acronym & Description \\
\hline $\begin{array}{l}\text { Connection with the main } \\
\text { ecological structure of the } \\
\text { landscape }\end{array}$ & CMES & $\begin{array}{l}\text { It assesses the distance of the farm in relation to the } \\
\text { nearby fragments of natural vegetation, mainly forest } \\
\text { cover and bodies of water. }\end{array}$ \\
\hline $\begin{array}{l}\text { Extension of external } \\
\text { connectors }\end{array}$ & EEC & $\begin{array}{l}\text { Evaluates the percentage of the linear extension of } \\
\text { live fences, present in the perimeter of the farms. }\end{array}$ \\
\hline $\begin{array}{l}\text { Diversification of external } \\
\text { connectors }\end{array}$ & DEC & $\begin{array}{l}\text { Evaluates the diversity of live fences or hedges } \\
\text { located on the perimeter of the major } \\
\text { agroecosystem. }\end{array}$ \\
\hline $\begin{array}{l}\text { Extension of internal } \\
\text { connectors }\end{array}$ & EIC & $\begin{array}{l}\text { Evaluates the percentage of the linear extension of } \\
\text { the rows of vegetation, but internally. }\end{array}$ \\
\hline $\begin{array}{l}\text { Diversification of internal } \\
\text { connectors }\end{array}$ & DIC & Evaluates the diversification of internal live fences. \\
\hline $\begin{array}{l}\text { Uses and conservation of the } \\
\text { soil }\end{array}$ & US & $\begin{array}{l}\text { This parameter evaluates the percentage distribution } \\
\text { of different coverages. }\end{array}$ \\
\hline Management of weeds & MW & $\begin{array}{l}\text { Evaluates the management practices and systems of } \\
\text { weed plants. }\end{array}$ \\
\hline Other management practices & OP & $\begin{array}{l}\text { Is an indicator that expresses the types of production } \\
\text { systems (ecological, conventional, or in transition) of } \\
\text { each farm. }\end{array}$ \\
\hline Perception-Awareness & PA & $\begin{array}{l}\text { Evaluates the degree of conceptual clarity and } \\
\text { awareness of producers regarding agrobiodiversity. }\end{array}$ \\
\hline Level of capacity for action & CA & $\begin{array}{l}\text { Evaluates the capacities and possibilities of farmers } \\
\text { to establish, maintain or improve their MAS }\end{array}$ \\
\hline
\end{tabular}

Source: León-Sicard, 2014

Each parameter is evaluated on a numerical scale of 1-10, whose qualitative interpretation corresponds to the following equation (Equation 1):

$M A S=C M E S+E E C+D E C+E I C+D I C+U S+M W+O P+P A+C A .(1)$ 
The scale of interpretation of the status of the MAS is indicated in the next table. Table 2. Interpretation of the Main Agroecological Structure.

\begin{tabular}{cl}
\hline Value & \\
\hline $80-100$ & Strongly developed \\
$60-80$ & Moderately developed \\
$40-60$ & Slightly developed \\
$20-40$ & Weakly developed, with cultural potential to complete it \\
$<20$ & $\begin{array}{l}\text { No structure or weakly developed structure, no cultural potential to establish } \\
\text { it }\end{array}$
\end{tabular}
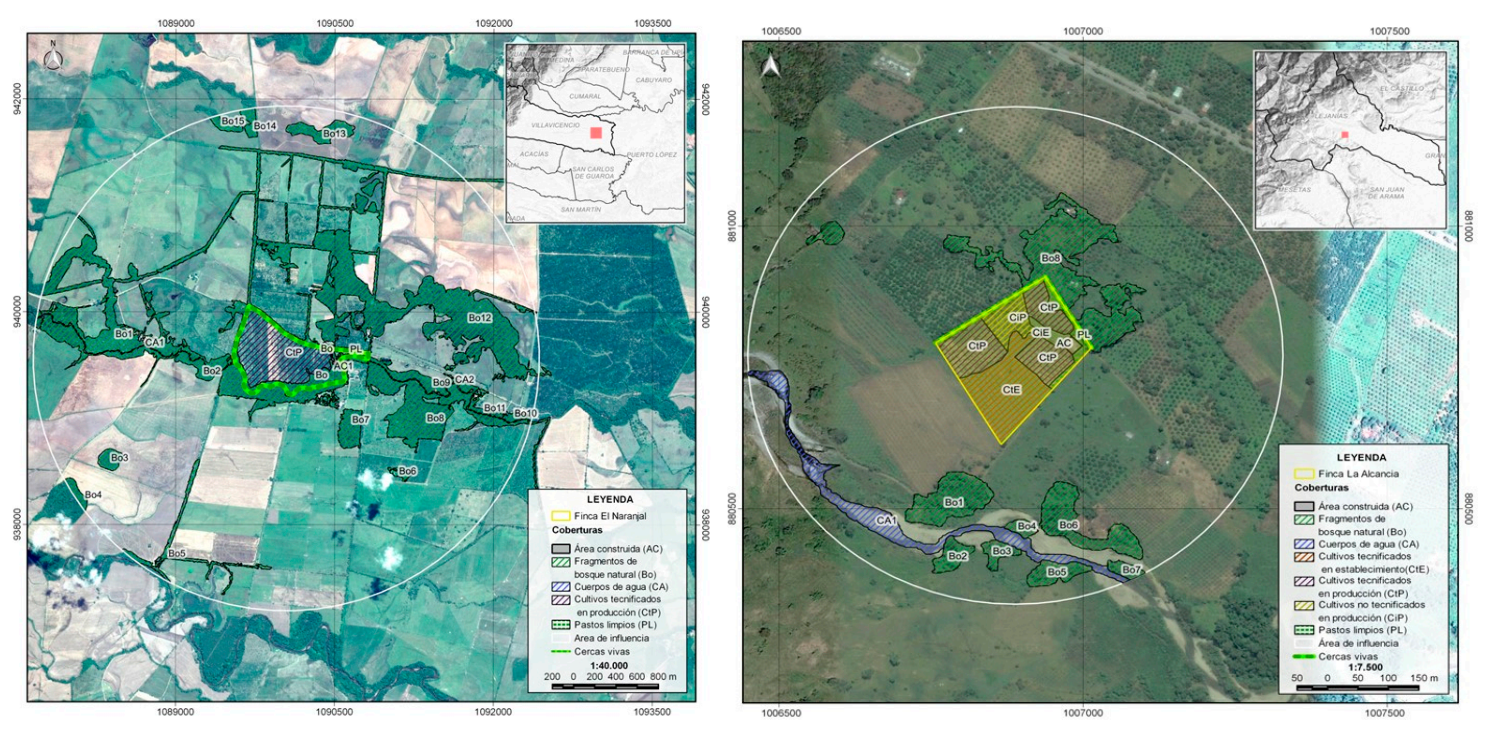

Figure 1. Connectivity with the Main Ecological Structure of the Landscape (EEP) of the farms "Agrícola El Naranjal" (left.) And "La Alcancía" (right). Note the difference in bodies of water and gallery forests between the two farms (Source: professor Alejandro Cleves Leguízamo) 


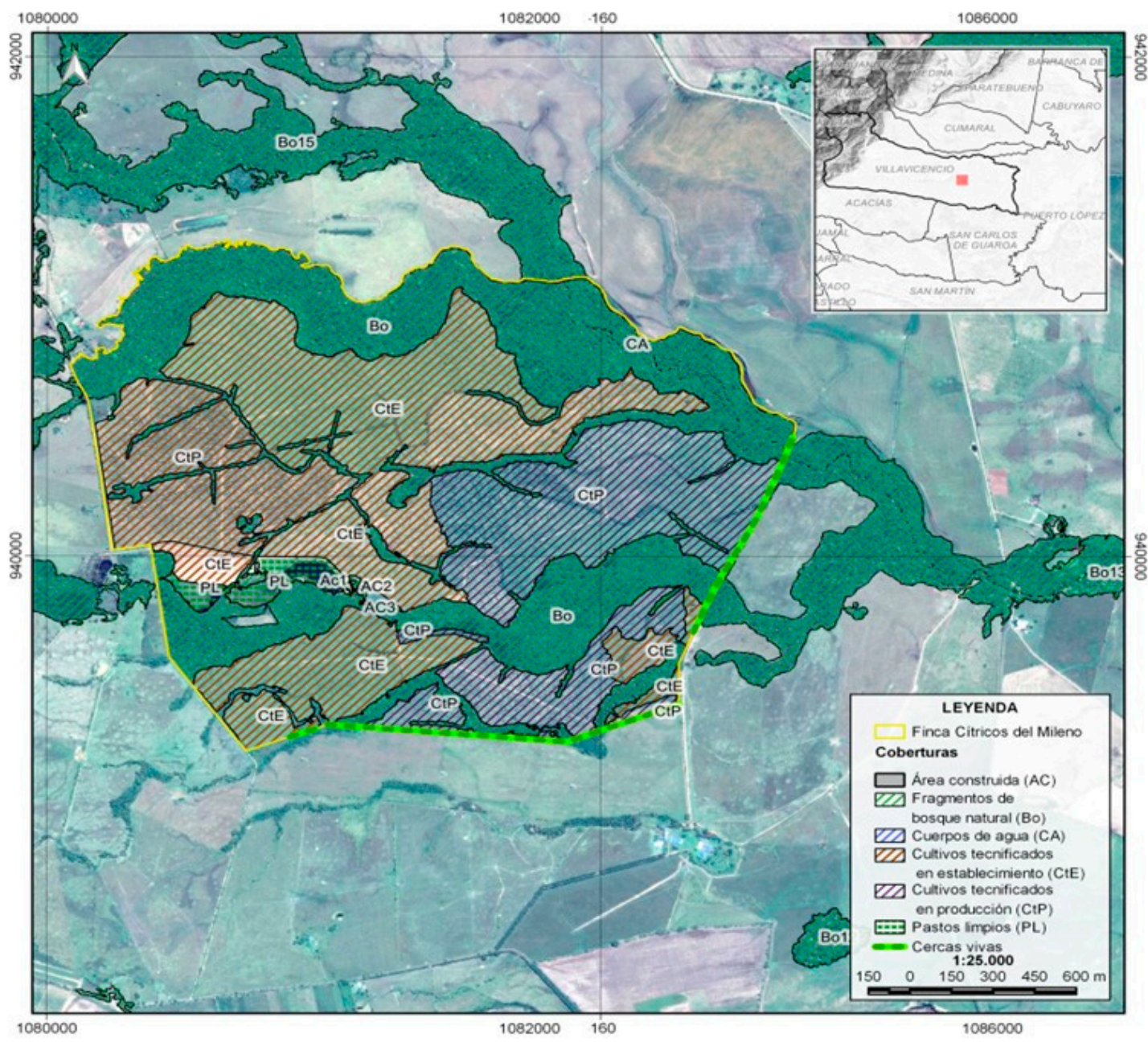

Figure 2. External and internal connectors of the farm "Cítricos del Milenio" in the Colombian Orinoquia, showing a strong connection (Source: professor Alejandro Cleves-Leguízamo)

\section{Applications of the MAS}

The MAS was applied for the first time in Colombia in an study conducted by LeónSicard et al., (2014) who compared 6 ecological horticultural farms (from 20 to 0.16 hectares), in the savannah of Bogotá using the ten general criteria exposed. They found values of MAS between 47 (slightly developed) and 81 (strongly developed), which revealed substantial differences in management between the farms studied and a high degree of isolation from them with the ecological structure of the landscape. This first exercise indicated that the index could be applied in different socioeconomic conditions and in different natural regions of the country. To this end, new studies were carried out in other areas of peasant production in Colombia (Anolaima, Quipile and Pulí in the department of Cundinamarca), in coffee agroecosystems with greater biodiversity.

In this sense, Córdoba and León-Sicard (2013) studied the ecosystem and cultural resilience of six coffee agroecosystems (three ecological and three conventional) in Anolaima (Colombian Andes), regarding climate variability. All the ecological farms presented better MAS conditions and greater resilience than the conventional ones, although all were located in a region characterized by the soil susceptibility to mass movements and responded to a common history of settlement and similar socioeconomic conditions. In another study conducted in coffee agroecosystems of 
Quipile and Puli (Cundinamarca), Cepeda et al. (2014) evaluated the MAS in an area with different degrees of agricultural intensification, comparing the results with the typing methodology of Moguel and Toledo (1999). In different types of coverage, the authors measured local variables associated with agricultural management (richness, density and average height of trees, average density and height of coffee, weed richness, percentage of canopy cover and distance to the nearest forest as a factor of the landscape) and determined the types and frequency of application of agrochemicals and other cultural management variables.

The authors found out good correlation of the classification of Moguel and Toledo (1999) with the classification proposed in the study. In addition, they determined that the floral diversity and natural spaces close to the crop substantially affect the richness of the visiting bees of the coffee. They proposed that the MAS, through diversified productive arrangements with high internal and external connectivity, propitiates synergistic effects that increase the wealth of bees within the coffee field and enhance their conservation and ecological function of pollination.

Another study carried out to explain the socio-environmental reasons of voluntary urban migrants towards intentional rural communities (Pinzón, 2014), assessed the ecosystemic effects of this migration at the level of the changes that occurred in the MAS of the farms. The study took place in three ecovillages of the department of Cundinamarca (Varsana located in the municipality of Granada, El Retoño in the municipality of Silvania and Aldea Feliz in the municipality of San Francisco), using ethnographic techniques and vegetation sampling.

The results showed that the migrants contributed positively in the improvement of the agrobiodiversity of the farms, measured through the MAS. Varsana (whose inhabitants arrived in 1979) went from an initial MAS of 18 (weakly developed) to values of 80 (strongly developed) in 2013. El Retoño went from 26 to 81 in 15 years (1998-2013) and Aldea Feliz of 63 to 92 in 7 years (2006-2013). Such modifications were linked to the personal motivations of migrants who seek in environments other than the urban, elements of healthy living, satisfaction of spiritual aspirations and vindication of values of solidarity and respect, accompanied by administrative and economic structures of solidarity type.

Likewise and in order to assess the role of the MAS in the general resilience of citrus agroecosystems to climatic variability in conditions of the Colombian Orinoquia, Cleves-Leguizamo and Jarma-Orozco (2014) and Cleves-Leguizamo et al., (2016) studied this characteristic in 18 farms located in the Orinoquia foothills. They found out high correlation between the MAS and the decrease in the number of phytosanitary controls, carried out by the growers of Orange (Citrus sinensis (L.) Osbeck) var. Valencia, as well as positive correlations with the productivity of the farms studied.

Finally, León-Sicard et al (2015), conducted a preliminary exercise to include agroecosystems (beyond the Corine Land Cover classification) in the national ecosystem map of Colombia and for this they proposed to value the MAS as an agroecosystem connectivity criterion that could be represented even in maps at 1 : 100,000 scale.

The previous examples show that the Main Agroecological Structure of the major agroecosystems can become a valuable tool for the study and planning of the use of agroecosystems, both at the level of their internal management and in matters related to the management territorial planning (Cleves et al, 2017). 
At farm level scale, the MAS facilitates the understanding of the interrelationships that agrobiodiversity provides. Although specific studies have not been made yet in this field, it is possible to advance the hypothesis of high and positive relationships between MAS and the abundance of pollinators or natural enemies and of varied intra - and interspecific relationships of different organisms, responsible for being agents or vectors of diseases and damage to crops. Included in this category is the soil biodiversity, which can be improved by the influence of agrobiodiversity management, via the reinforcement of the MAS.

On the other hand, as already noted by León-Sicard (2014), the MAS can help in planning the use of the farm, incorporating the notion of potential MAS, that is, the location, layout and implementation of better and more diversified internal and external corridors, including the management of patches of natural vegetation within the farms (ecosystems within agroecosystems). The MAS allows calculating the selection of flower banks and the introduction of certain shrub or forest species, which have already been proven to be beneficial for the production or control of insect populations, in the style of intensive silvopastoral systems (Nicholls et al., 2001; van der Putten et al., 2001).

On the other hand, the MAS provides explanations, at the farm scale, of landscape connectivity. It is no longer a matter of considering the biological corridors or the patches of vegetation or the remaining forests as loose pieces in the landscape. The MAS allows them to be grouped around the agricultural production units themselves and therefore it makes visible a series of cultural relations (economic, social, symbolic and technological) hidden from the partial analysis of landscape ecology. In other words, the MAS is the entry of agricultural producers into the maps of the environmental planning of the territory.

Socio-ecological resilience recognizes that culture has a technological component that is incorporated by farmers in response to disturbances. From this perspective, the characterization of the MAS allows determining which cultural practices are necessary to increase agrobiodiversity (i.e. the development of agroforestry, the practice of allelopathy, the harvesting of water, the management of coverings and the use of entomopathogens). With these practices it is not only possible to increase yields, but also the quantity and variety of foods, creating strong connections with security processes, sovereignty and food autonomy, improving the nutritional processes of farmers and their communities (Pirachicán, 2014).

The above points demonstrate the relevance of the evaluation of the MAS as a highly useful methodology for decision-making. It can help farmers make adjustments in their agroecosystems, so that by increasing connectivity and biodiversity, the resilience and productivity of their agricultural and livestock units can be increased and, as a consequence, their income, level of life and food autonomy.

At the administrative level, the MAS can become an important input for the design of public development policies with a territorial approach, based on local needs and the active participation of farmers. Finally, the MAS can also become a useful theoreticalpractical instrument to advance the taxonomy of agroecosystems, an issue that the science of agroecology has not yet addressed.

\section{References}

Ahn, H. Speculation in the financial system as a dissipative structure. Seoul J. Econ. 1998 Vol 11(3), 295-319. 
Almendro, M., Weber, D. Dissipative processes in psychology: From the psyche to totality. Int. J. Transpers. Stud. 2012 Vol 31(2), 1-22.

Altieri, M. El estado del arte de la agroecología: revisando avances y desafíos, (pp.77102). En: León-Sicard, T. y Altieri, Vertientes del Pensamiento Agroecológico. Fundamentos y Aplicaciones. 1a edición. Universidad Nacional de Colombia Instituto de Estudios Ambientales, 2010. Bogotá, Colombia.

Altieri, M., Liebman, S., Magdoff, M., Norgaard, F., Sikor, R., \& Thomas, O. Agroecología: Bases científicas para una agricultura sustentable. NordanComunidad, 1999. Montevideo Uruguay, (325 pp).

Altieri, M. and Koohafkan, P. Enduring farms: climate change, smallholders and traditional farming communities. Environment and Development 2008. (Vol 6). Third World Network (TWN), Kuala Lumpur Malaysia.

Altieri, M. and Nicholls, C. Cambio climático y agricultura campesina: impactos y respuestas adaptativas. LEISA Revista de Agroecología. 2009. Vol 24, 5-8.

Ángel, A. La trama de la vida. Bases ecológicas del pensamiento ambiental. $1^{a}$ ed. Ministerio de Educación Nacional Colombia - Universidad Nacional de Colombia, Instituto de Estudios Ambientales (IDEA). Bogotá, Colombia 1993 (pp.77)

Ángel, A. La fragilidad ambiental de la cultura. $1^{\text {a }}$ ed. Universidad Nacional de Colombia-Instituto de Estudios Ambientales, Bogotá, Colombia. 1995 (127 pp).

Ángel, A. El reto de la vida. Ecosistema y cultura. Una introducción al estudio del medio ambiente. $1^{\text {a }}$ ed. Ecofondo. Bogotá, Colombia. 1996 (109 pp).

Bazykin, A., Khibnik, A., Aponina, E. A model of evolutionary appearance of dissipative structure in ecosystems. J. Math. Biol. 1983. Vol 18, 13-23. doi:10.1007/BF00275907

Cepeda, J. Gómez, D. and Nicholls, C. La estructura importa: Abejas visitantes del café y Estructura Agroecológica Principal (EAP) en cafetales. 2014.Rev. Colombiana de Entomología, Vol 40(2), 241-250.

Cleves-Leguizamo, J.A., Jarma-Orozco, A. Characterization and typification of citrus production systems in the department of Meta. Agron. Colomb. 2014. Vol 32(1), 113-121.

ISSN

01209965. http://dx.doi.org/10.15446/agron.colomb.v32n1.42164.

Cleves-Leguizamo, A., Toro, J., León-Sicard, T. La estructura agroecológica principal (EAP). Metodología para analizar la biodiversidad y resiliencia en agroecosistemas. (pp. 1-26). En: Memorias Congreso Nacional de Medio Ambiente (CONAMA) - 2016. Fundación Conama. Madrid, España.

Cleves-Leguízamo, A., Toro, J., Martínez, L. y León-Sicard, T. La Estructura Agroecológica principal (EAP): novedosa herramienta para planificación del uso de la tierra en agroecosistemas. En: Revista Colombiana de Ciencias Hortícolas 2017 Vol $11 \quad$ (2) Pp 441 - $449 \quad$ Doi: http://dx.doi.org/10.17584/rcch.2017v11i2.7350

Córdoba, C. and León-Sicard, T. Resiliencia de sistemas agrícolas ecológicos y convencionales frente a la variabilidad climática en Anolaima (Cundinamarca Colombia). Agroecología 2013. Vol 8(1), 21-32.

Dalgaard, T., Nicholas, T., Hutchings, J., y Porter, R. Agroecology, scaling and interdisciplinary. Agriculture, Ecosystems and Environment 2003. Vol 100(1), 39-51. Doi: 10.1016/S0167-8809(03)00152-X

Deng, X., Zheng, S., Xu, P., Zhang, X. Study on dissipative structure of China's building energy service industry system based on brusselator model. J. Clean. Prod. 2017. Vol 150, 112-122. Doi:10.1016/j.jclepro.2017.02.198

Duarte, O. Tipificación de fincas en la comarca de San Gil, Colombia, con base en una encuesta dinámica (pp. 201-220). En: Tipificación de Sistemas de Producción Agrícola, $1^{\text {a }}$ ed. Escobar \& Berdegué editores. 1990. Santiago de Chile, Chile. 
Emig, C. Relations entre l'espèce, structure dissipatrice biologique, et l'écosystème, structure dissipatrice écologique. Contribution à la théorie de l'évolution des systèmes non-en équilibre. C. R. Acad. Sci. Paris, 1985. Vol 8, 323-326.

Fonseca, J. y Cleves-Leguizamo, J.A. Agroecología y cambio climático: dos retos urgentes para la humanidad. (pp. 69-81). En Ciudadanía ambiental, crisis de la agricultura convencional y desafíos para una agroecología orientada hacia el desarrollo rural. Universidad Nacional Abierta y a Distancia (UNAD). 2015. Bogotá - Colombia.

Gliessman, S. Agroecology: researching the ecological basis for sustainable agricultura (In Spanish) Agricultura y desarrollo, 1991. Vol 1(1), 45-48.

León-Sicard, T. Perspectiva ambiental de la agroecología: la ciencia de los agroecosistemas. Bogotá, Universidad Nacional de Colombia - Instituto de Estudios Ambientales. $1^{\text {a }}$ ed. 2014. Serie IDEAS 23, 398 p.

León-Sicard, T. Medio ambiente, tecnología y modelos de agricultura en Colombia. Hombre y arcilla. $1^{a}$ ed. 2007. ECOE- IDEA, Bogotá, (pp. 287).

León-Sicard, T. Agroecología: desafíos de una ciencia ambiental en construcción. En: León-Sicard, T. y Altieri, M., Vertientes del pensamiento agroecológico: fundamentos $y$ aplicaciones.. $1^{\text {a }}$ ed. 2010a Editorial Sociedad Científica Latinoamericana de Agroecología - Universidad Nacional de Colombia, Bogotá, (pp 53-77).

León-Sicard, T. Regulación biológica en agricultura de pequeña escala: un enfoque desde la sostenibilidad. En: León-Sicard, T. y Altieri, M., Vertientes del pensamiento agroecológico: fundamentos $y$ aplicaciones. $1^{\text {a }}$ ed. $2010 \mathrm{~b}$. Editorial Sociedad Científica Latinoamericana de Agroecología - Universidad Nacional de Colombia, Bogotá, (pp. 271 -293).

León-Sicard, T. Clavijo, N., Córdoba, C y Gomajoa, L. Lineamientos conceptuales y metodológicos para cartografiar agroecosistemas en el mapa nacional de ecosistemas de Colombia (escala 1:100.000). Bogotá. Informe final Contrato Interadministrativo 352 de 2014 entre el Instituto de Hidrología, Meteorología y Estudios Ambientales de Colombia (IDEAM) y la Universidad Nacional de Colombia, Instituto de Estudios Ambientales (IDEA). 2015. 96 p.

León-Sicard, T., Mendoza, T. y Córdoba, C. La Estructura Agroecológica Principal de la Finca (EAP): un concepto útil en agroecología. Agroecología. 2014. Vol 9 (12), 55-66.

Marchettini, N., Del Giudice, E., Voeikov, V., Tiezzi, E. Water: A medium where dissipative structures are produced by a coherent dynamics. J. Theor. Biol 2010. Vol 265, 511-516. Doi:10.1016/j.jtbi.2010.05.021

Martinez, H. and Carlsson, G. Genetic nets and dissipative structures: An algebraic approach. Bull. Math. Biol. 1974. Vol 36, 183-196. Doi:10.1007/BF02458602.

Martínez, R. Agroecología: atributos de sustentabilidad. InterSedes: Revista de las Sedes Regionales, [en línea] 2002. 3 (5). (pp. 25-45). Universidad de Costa Rica Ciudad Universitaria Carlos Monge Alfaro. Disponible en:<http://www.redalyc.org/articulo.oa?id=66630504> ISSN 2215-2458

Maturana, $H$. and Varela, F. De máquinas y seres vivos: autopoiesis: la organización de lo vivo, $1^{\text {a }}$ ed. 2004. Editorial Universitaria LUMEN. (pp. 73-74), Buenos Aires, Argentina.

Méndez, E., y Gliessman, S. Un enfoque interdisciplinario para la investigación en agroecología y desarrollo rural en el trópico latinoamericano. En: Manejo integrado de plagas y agroecología 2002. Vol 64, (pp: 5-16). Costa Rica.

Moguel, P. y Toledo, V. Biodiversity conservation in traditional coffee systems in Mexico. Rev Conservation Biology 1999. Vol 13 (1) pp: 11-21.

Nicholls, C. Parrilla, I. and Altieri, M. The effects of a vegetational corridor on the abundance and dispersal of insect biodiversity within a northern California organic vineyard. Landscape Ecology. 2001. Vol 16(2), 133-146. 
Pinzón, M. Transformación de la Estructura Agroecológica Principal en comunidades intencionales rurales (Eco aldeas). Tesis de Maestría. Facultad de Ciencias Económicas, Universidad Nacional de Colombia. 2014. Bogotá.

Pirachicán, E. Autonomía alimentaria en sistemas agrícolas ecológicos y convencionales en Anolaima (Cundinamarca). Tesis de Maestría. Facultad de Ciencias Económicas, Universidad Nacional de Colombia. 2014. Bogotá.

Prigogine, I. ¿Tan Solo Una llusión? . Tusquets Editores S.A., 1983. Barcelona.

Prigogine, I., Lefever, R. Theory of Dissipative Structures, in: Haken, H. (Ed.), Synergetics: Cooperative Phenomena in Multi-Component Systems. Vieweg Teubner Verlag, Wiesbaden, 1973. pp. 124-135. Doi:10.1007/978-3-663-01511610.

Pulselli, R.M., Simoncini, E., Tiezzi, E. Self-organization in dissipative structures: A thermodynamic theory for the emergence of prebiotic cells and their epigenetic evolution. Biosystems 2009. Vol 96, 237-241. Doi:10.1016/j.biosystems.2009.02.004

Segel, L.A., Jackson, J.L. Dissipative structure: An explanation and an ecological example. J. Theor. Biol. 1972. Vol 37, 545-559. Doi:10.1016/00225193(72)90090-2

Shvartsev, S.L. Self-organizing Abiogenic Dissipative Structures in the Geologic History of the Earth. Earth Sci. Front. 2009. Vol 16, 257-275. Doi:10.1016/S1872-5791(08)60114-1

Toledo, V. Modernidad y Ecología: La nueva crisis planetaria. Ecología Política 1990. Vol 3, 9-22.

Tuzinkevich, A. and Frisman, Y. Dissipative structures and patchiness in spatial distribution of plants. Ecol. Modell. 1990. Vol 52, 207-223. Doi:10.1016/03043800(90)90016-A

Tylor, B. E. Primitive culture. Londres - John Murray 1871. (trad. cast: Cultura primitive, Madrid, Ayuso, 1977).

Van der Hammen, T. Plan ambiental de la Cuenca Alta del río Bogotá (Análisis y Orientaciones para el Ordenamiento Territorial), Corporación Autónoma Regional de Cundinamarca, CAR, 1998. Bogotá, (pp. 142).

Van der Hammen, T. y Andrade, G. Estructura ecológica principal de Colombia primera aproximación. Ministerio de Ambiente, Vivienda y Desarrollo Territorial, Instituto de Hidrología, Meteorología y Estudios Ambientales. 2003. (pp.74).

Van der Putten W., Vet., J. Harvey, F. and Wackers. Linking above - and belowground multitrophic interactions of plants, herbivores, pathogens, and their antagonists. Trends in Ecology \& Evolution. 2001. Vol 16, 547-554.

Wagensberg, J. Ideas sobre la complejidad del mundo, 4th ed. 1998. Tusquets Editores S.A., Barcelona.

Wang, J. Dissipative structure theory and strategy for systematic control of field weeds. Chinese J. Ecol. 1992. Vol 11, 49-52

Zhan, K. and Sheng, X. Prigogine and theory of dissipative structure. Shanxi Sci. Technol. 1998. Press Xi'an, China.

Zhao, C., Hobbs, B.E., Mühlhaus, H.B., Ord, A. Finite element modelling of dissipative structures for nonequilibrium chemical reactions in fluid-saturated porous media. Comput. Methods Appl. Mech. Eng. 2000. Vol 184, 1-14. Doi:http://dx.doi.org/10.1016/S0045-7825 (99)00449-1 